\title{
ELIOTS COURT PRESS
}

\section{Decorative Blocks and Initials}

BY HENRY R. PLOMER

$7 \mathrm{HE}$ work of the Eliots Court press was mainly that of a trade house and much of it lies behind the imprints

1 of other firms. Hence in order to be able to recognize its work, familiarity with at least the more important ornaments and initial letters used by the printers at that house is essential. The task is not as easy as might be thought. At the very outset one finds oneself up against an old custom of the printing trade, that of copying each other's blocks. Sometimes, no doubt, this was done for sheer want of originality or because a particular letter or ornament was attractive ; but more often for the more questionable purpose of placing on the market a cheap edition of another man's copyright by the issue of a pirated copy, as in the well-known instance of John Day's $A B C$ and little catechism, which was pirated by Roger Ward and was so closely imitated that Day himself could not tell the difference between the original issue and the piracy.

Again, printers often found it necessary to copy their own blocks, and doubtless most offices kept in stock several blocks of the same letter or ornament which, on a change of ownership or the dispersal of the printing material, came into other men's hands.

The Eliots Court printing-house, for example, purchased largely from Bynneman's office at his death both type and blocks, but doubtless some passed into other printing-houses. At any rate, we frequently find a similarity between the 
blocks used by Bollifant and his successors and associates and those in the hands of other printers; such similarity involving almost microscopical examination to tell the difference between them, or whether. there is any difference at all. So that it behoves the bibliographer to go warily, for while it is an easy thing to carry in one's head the general character of any block, it is both dangerous and misleading to ascribe a book to a certain printing-house on the strength of one's recollection only, and this caution is doubly necessary when dealing with the work of this printing-house. The following notes have been brought together as some kind of guide to the identification of the workmanship of this press.

\section{Decorative Blocks.}

Down to the time when the printers in Eliots Court began to print books in folio, Edmund Bollifant and his partners

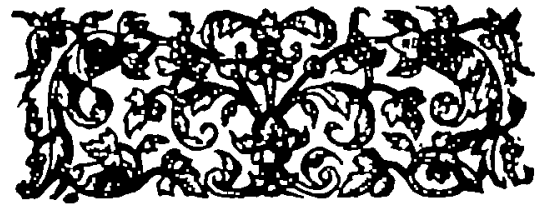

No. I.

seem to have followed the practice of Henry Bynneman, in a very sparing use of decorative blocks. Their custom was to fill in blank spaces with sections of what has been called the 'lace' ornament, which was common to all printers. They also used it to form borders to title-pages, with very good effect.

The earliest decorative block met with is one measuring $52 \times 19 \mathrm{~mm}$. showing foliage conventionally treated (No. I), and was used both as ornament for title-pages, head-, or tailpieces as desired. This they had obtained with the rest of 
the material dispersed on Bynneman's death, and it will be seen in his edition of Roger Ascham's epistles printed in I 581 (sig. II I verso) and also in Joan. Ravisii . . Dialogi, I 58I (sig. Aij). Bollifant used it as an ornament to the titlepage of Twyne's De rebus Albionicis in 1590, and it figures in the books printed at this press down to 1622 and possibly later.

A tail-piece representing a Gorgon's head with pendants

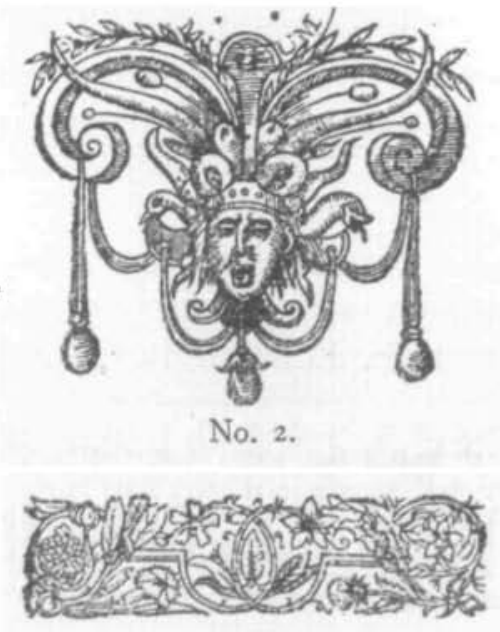

No. 3 .

(No. 2) was another of Bynneman's blocks that they began to use at once, as it appears at the end of Edm. Bunny's Treatise terding to Pacification which formed the Appendix to Robert Parsons's Book of Christian Exercise printed by N. Newton and A. Hatfield for John Wight in $15^{84}$. This was sometimes used as an ornament for the title-page.

Another small block (No. 3), identified as Bynneman's and found in his edition of the Dialogi of Ravisius, was frequently used by the Eliots Court printers in the decoration of duodecimos and other small books, but does not begin to make 
its appearance until after 1600 . It will be seen in Joseph Hall's Polemice sacra (sig. A2), printed by A. Hatfield in I6II, and passed to Edw. Griffin, who used it in the same author's $Q u o$ Vadis? with another of the same size and character, which could probably be traced to the same source.

After 1600 the ornamental blocks become more numerous and varied. No. 4, showing two cherubs blowing horns which become floral filials forming cornucopiae, filled with fruit, measuring $70 \times 22 \mathrm{~mm}$., is both artistic and effective. It is found in a pamphlet entitled a Copy of a Letter written by $E . D$., printed by M. Bradwood in 1606 , 4 to (sig. $\mathrm{C}_{4} \mathrm{v}^{\circ}$ ),

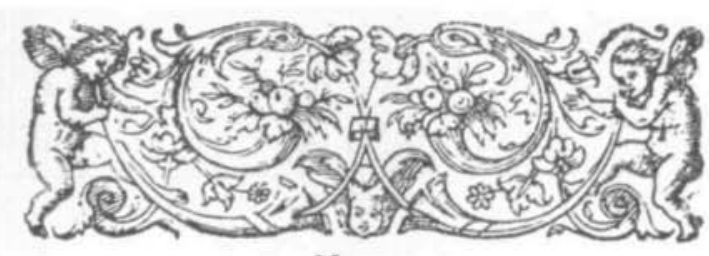

No. 4 .

and is noticeable for the marked difference between the leftand right-hand sides. It often happens that the cutting of the left-hand side of a block is clumsier, and differs in detail from the other, but it is seldom so marked as in this example. Not only is the outstretched arm of the cherub on the left much heavier and longer than that of his fellow on the right; but from the bell-flower on the right issues a spiral that passes over the head of the cherub; but his companion on the left is so close to the flower that the spiral on that side becomes tangled in his hair. This block passed in due course to Edward Griffin.

This same book also presents us with an example of what is, of all the Eliots Court press blocks, the most puzzling (No. 5). It is found in use by all the printers without exception ; but in books printed by Felix Kyngston is found a block of exactly 
the same size, and so like that close comparison only reveals a slight difference in the tops of the central fleur-de-lis, while the tips of the adjoining stems are curled over in the E.C.P. block but are broken off in Kyngston's. It is the only instance in which so close a resemblance is found, and the

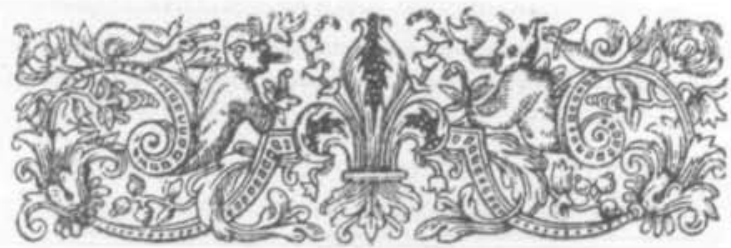

No. 5 .

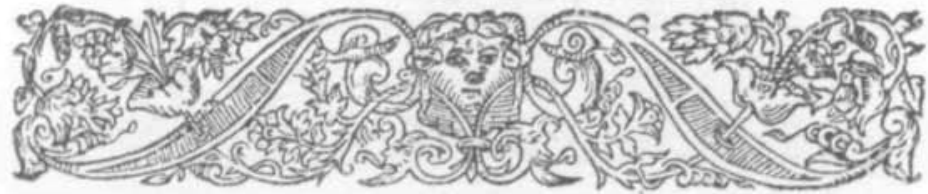

No. 6.

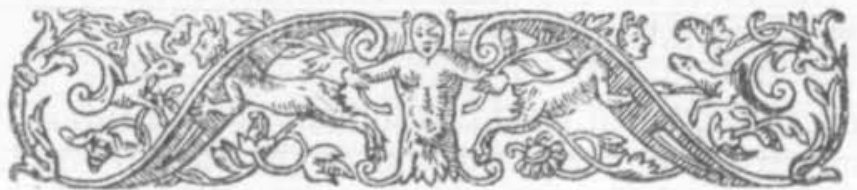

No. 7 .

explanation may be that it was a stock pattern supplied to several printing-houses.

Nos. 6 and 7 are met with on the title-page of Du Bartas's Babilon, printed by Bollifant in 1596 , and continued in use till 1640. The top one began to crack longitudinally about I600 until it split nearly across, and the different stages of the crack serve as a guide to the date of printing.

The block No. 8, used on the title-page of The Copy of a 
Letter, can be traced in the hands of Hatfield, Bradwood, the Griffins, and Haviland, and was still in use in 1650 , and No. 9, also found in the same book, is a well-known headpiece used at this press between 1606 and 1644 .

Edward Griffin the first introduced the block showing the Hebrew word for the Deity, with a border of glory. It

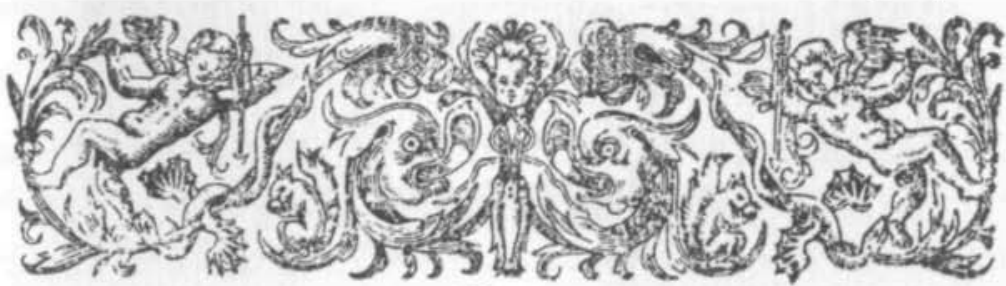

No. 8.

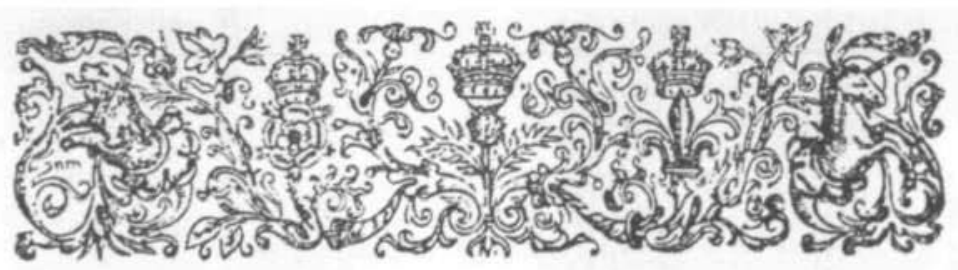

No. 9.

passed to Haviland and is found as a head-piece in numerous volumes of sermons.

When Bradwood went to Eton to print Sir H. Savile's Chrysostom, he took with him No. Io, a block showing an open book on cushion with sword and sceptre across it. As this is first met with in 1609 in a book printed for John Norton, it may have been procured from him. It was frequently used with side-pieces of a different character.

Four blocks of the national emblems, the rose, thistle, fleur-de-lis, and harp (No. II), were perhaps introduced into the office by Haviland about 1625 . They were still in use in 
1647. This set must not be confused with those without decorative matter, which were smaller, measuring only $35 \times$ $20 \mathrm{~mm}$. as against $40 \times 20 \mathrm{~mm}$.

George Purslowe also introduced one or two blocks that he had purchased from Simon Stafford, and these continued to

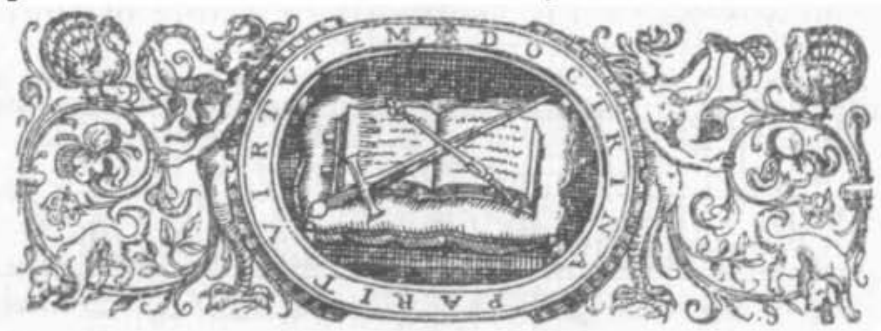

No. Io.

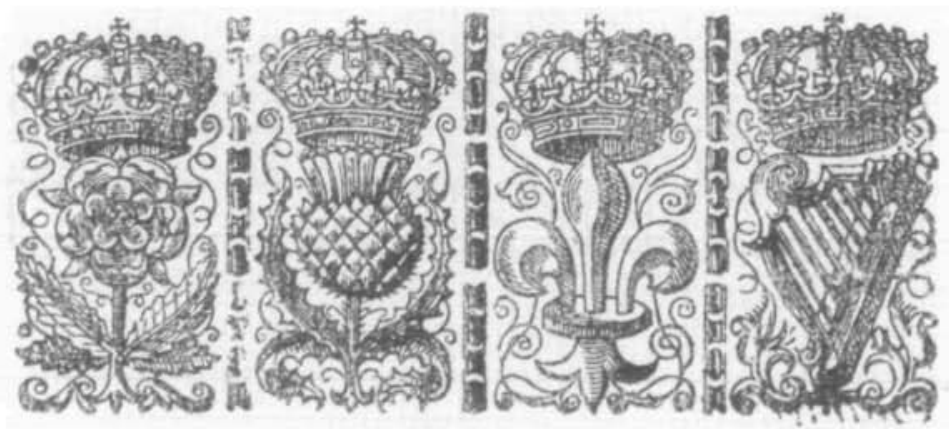

No. II.

be used by different members of the firm until the days of the Commonwealth. The one most frequently met with is a long narrow block showing in the centre an owl crowned with a hat.

A tail-piece used by Stafford in The late commotion of certain papists in Herefordshire, 1605,4 to, sig. B, is found in I633 in a book printed by Eliz. Purslow for N. Bourne, and S. Otes's $A n$ explanation of the Epistle of St. Iude, sig. F 5 verso. 
In 1620 George Purslowe, in printing the Rev. Elnathan Parr's Exposition on the Epistle to the Romans, used a curious head-piece (No. 12) to chap. xi, which at first seemed to be a combination of part of one he had obtained from Simon Stafford and part of No. 5. It now turns out to have been one of Henry Bynneman's blocks, and is found in his edition of J. Crespin's Lexicon Graeco-Latinum, I58I, 4to, sig. II 3. Space forbids any mention of the larger blocks used as head-

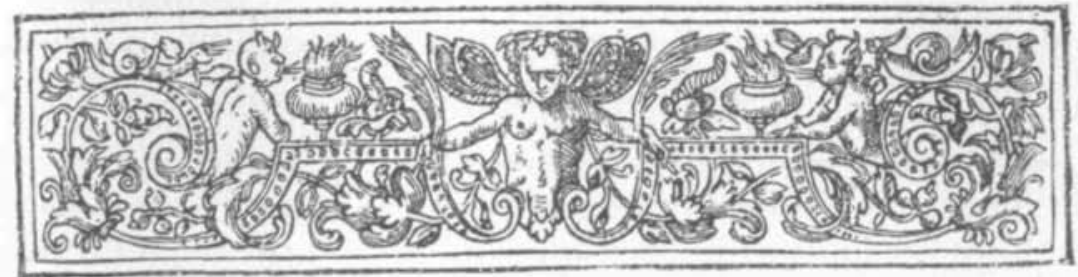

No. I2.

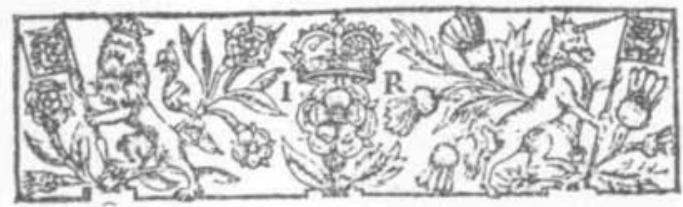

No. 13.

pieces in the folio books, and though there are many other small blocks met with in the books printed at this press, this section may be fittingly concluded with the description of a block used by Bradwood and his successors from 1604 till I640. In the centre is seen a rose crowned with the letters I.R. on either side. On the left is a lion crowned holding a flag showing a rose; on the right a unicorn holding a flag showing a thistle, while thistles and roses form the background. At the lower edge of the block are three incisions, as if it had once formed part of a larger design. Its measurement is 
$67 \times 19 \mathrm{~mm}$. (No. I3). This was one of the blocks used in books printed by the firm for John Norton, but is first found in use by M. Bradwood in 1604, in George Thomson's poem on the union of England and Scotland, and again two years later in the same author's $V$ index $V$ eritatis (sigs. $\mathrm{A}_{5}, \mathrm{BI}$ ), which was also the product of the Eliots Court press.

\section{Initial Letters.}

The Eliots Court press had a large and varied assortment of initial letters, many of them of great artistic merit. In the front rank must be placed the pictorial letters, all of which they got from Bynneman's stock, and which he in turn had obtained from Reynard Wolfe (Nos. I4, 15, 16, 17).

The large decorative letters (Nos. I8, I9, 20) also previously belonged to Bynneman, and one at least, the letter I, showing the storks, was used in 1573 by John Day in his quarto edition of Bishop Jewel's Vita et Mors, while others could probably be traced back to the printing-offices of Jugge and Cawood.

M. Bradwood took some of these large initials, notably a $\mathrm{K}$, down to Eton, and used them in the Chrysostom and other books that he printed there.

The set (Nos. 21, 22, 23, 24) which, for the sake of distinction, may be called the Apostle series is orre found in constant use throughout the whole career of this press. It is seen at its best in the folio Plutarch, printed by Arnold Hatfield in 1603 , and in this nearly every letter is found. But great caution is necessary in dealing with these initials, as several other printers in London at that time had letters of the same character. In most instances they represent the Apostles and their emblems, the Apostle himself wearing a halo. Each letter has a frame consisting of four pieces joined at each corner by a leaf and having a series of circles or studs in each section. 


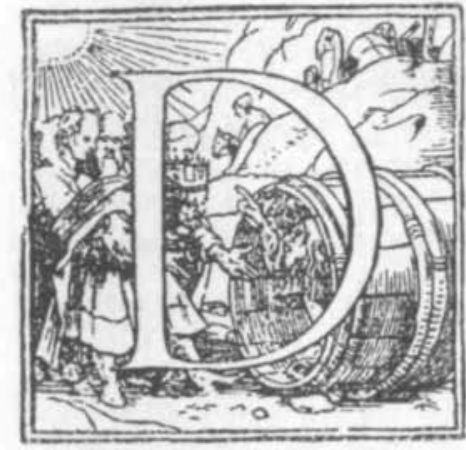

No. 14.

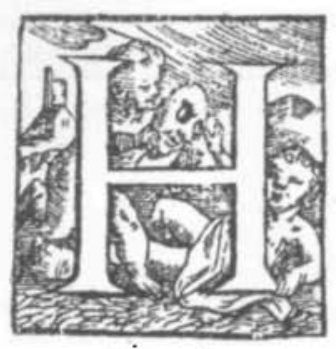

No. 16.

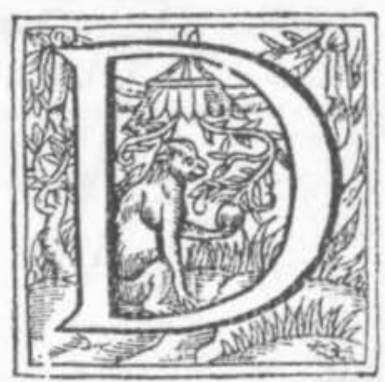

No. 15.

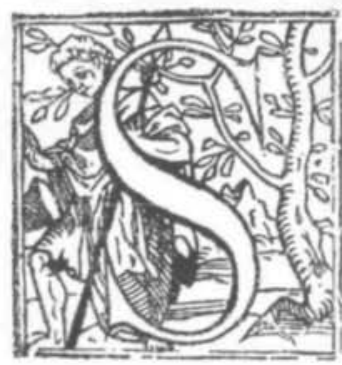

No. 17.

George Robinson and Henry Middleton both had sets of these letters, so did John and Thomas Dawson and John Beale. Middleton's set was so exactly like that used by the Eliots Court printers that only by putting them side by side and examining them closely can the points of difference be distinguished. It is then seen that Middleton's letters are better cut, and it seems very likely that the Eliots Court alphabet was copied from Middleton's, as in the letter H, where in Middleton's the figure is shown holding his staff in his right hand and the book in his left, in the E. C. P. letter 


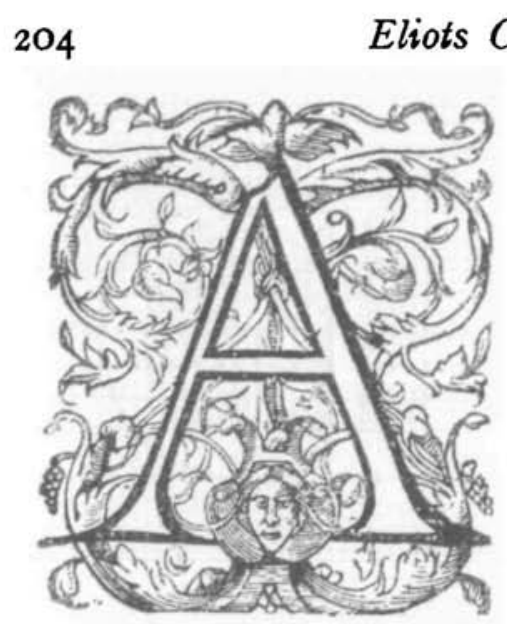

No. 18.

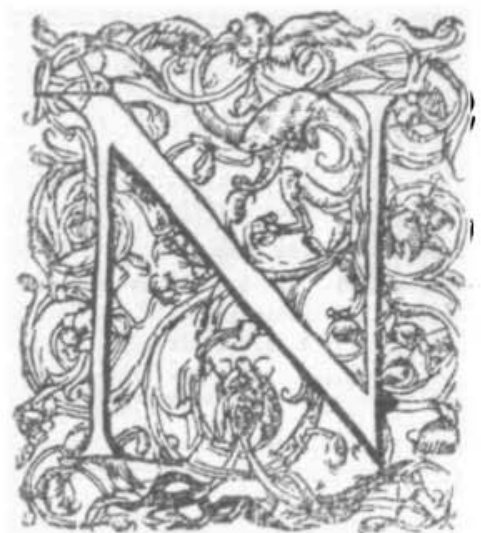

No. 19 .

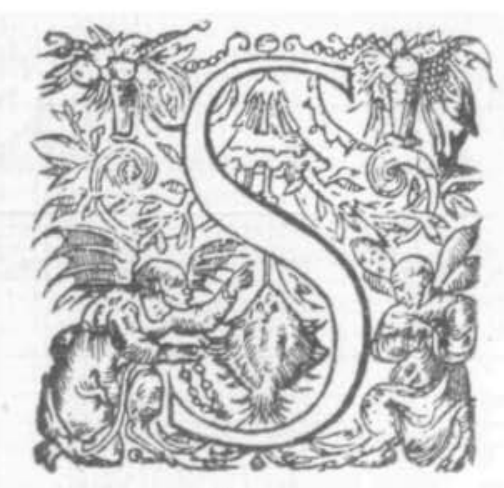

No. 20.

this is reversed, the staff being in the left hand and the book in the right. But it is the frame that furnishes the only effective way of identifying the Eliots Court Apostle letters, by noting the number of studs or circles in the upper and. lower sections. For example, the $\mathrm{F}$ in the Eliots Court alphabet has nine such circles in the top and ten at the 


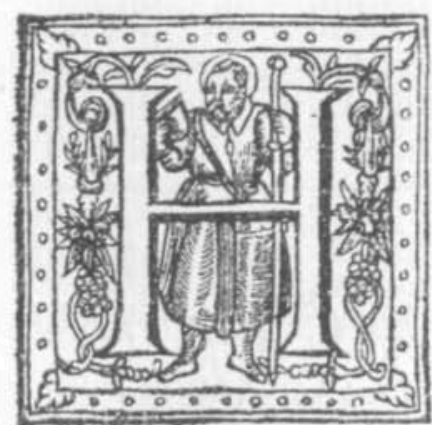

No. 21.

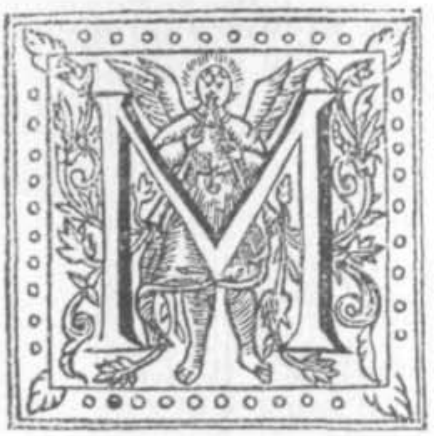

No. 23.

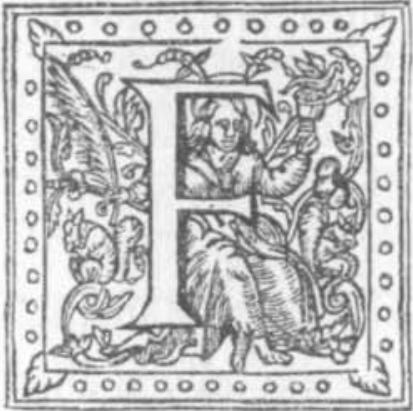

No. 22.

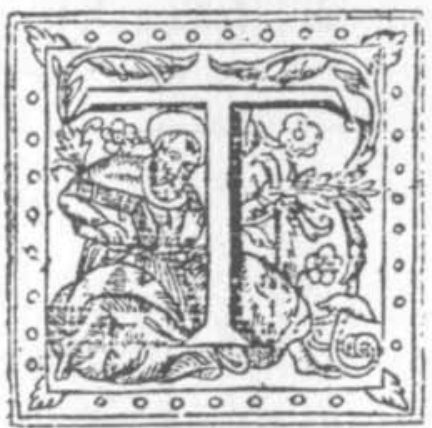

No. 24 .

bottom, whereas Middleton's $\mathbf{F}$ has twelve at the top and thirteen at the bottom. Again, the $\mathrm{M}$ belonging to the E. C. P. had ten studs at the top and ten at the bottom, whereas that in use by Middleton had eleven at the top and eleven at the bottom, and so on.

The set used in the Plutarch is the best test, and that set was in use until 1634, when John Haviland began to recut some of the letters, notably the letter $T$, which is found in two forms in some of his books. John Beale is found using 
an alphabet of this kind but without the frame. Altogether this alphabet is a very effective pitfall to unwary bibliographers, especially in the case of books that were the work of several printing-houses though bearing the imprint of one of the Eliots Court printers.

Another alphabet in constant use was Nos. 25, 26. This

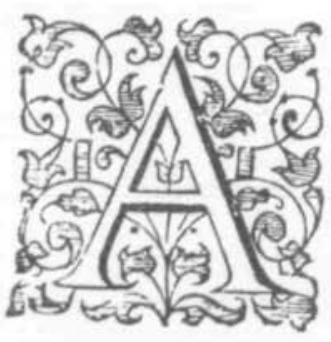

No. 25 .

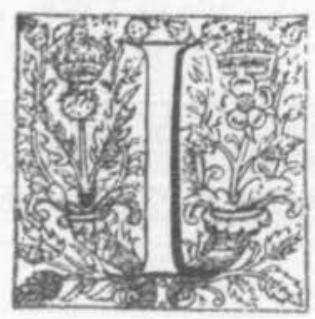

No. 27.

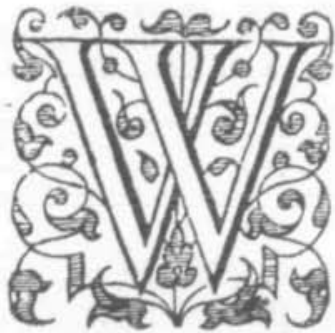

No. 26 .

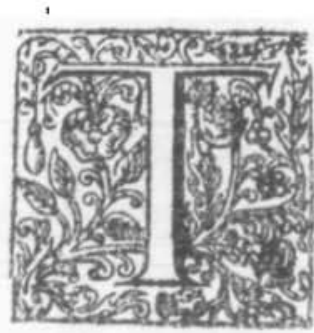

No. 28.

was a stock pattern supplied to many printers, and as a general rule is useless for bibliographical purposes, except in conjunction with other letters or ornaments. But there is one letter in the E. C.P. set which not only enables us to identify it as having previously belonged to Henry Bynneman, but also helps to identify any book in which it is found as a product of the Eliots Court printing-house. This is the letter A here 
reproduced, which shows a notable break in the right-hand upright. Such a break might have occurred in the letter A of another set, but it would have been a curious coincidence, and this particular break took place while it was in Bynneman's possession. This alphabet Bradwood also took with him to Eton and the defective $A$ appears in the Cbrysostom. It continued in use until 1623 , when it was in a very bad state.

Another set of decorative initials, of which the I and T are here shown (Nos. 27, 28), was frequently used with good effect by all the printers at this house, and by Bradwood especially. It is found in use until ${ }_{1627}$ and perhaps later.

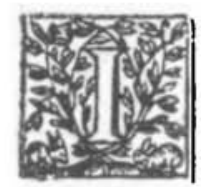

No. 29.

A chapter might be written on the numerous small initials stocked by this press. A happy hunting-ground for these is the folio edition of C. Wirtrung's Praxis Medicinae universalis, printed for Geo. Bishop in I598. Although it bears no printer's name it has on the title-page the Caducaeus device, which was one of those used by the Eliots Court printers, and was almost certainly from the press of Edmund Bollifant, although perhaps Hatfield had a share in the work. There are some in which flowers and fruit are chiefly used as decoration, notably the $\mathrm{B}$ showing a carnation and the $\mathrm{F}$ with the acorns and oak leaves.

Then there is the smaller set measuring $16 \times 16 \mathrm{~mm}$., of which the most frequently used letter is the I (No. 29), which shows two hares sitting facing each other at the foot of the letter. This letter may be fittingly termed the hallmark 
of the Eliots Court press, and is found in the hands of almost every printer connected with it from about 1593 to as late as 1622 , as will be seen from the following list :

1593. Biblia 8acra. Exc. G. B. R. N. and R. B. the assignes of Robert Barker, but having the Caducaeus device on some title-pages and almost entirely printed at the E.C.P., sig. A.

1598. E. Bollifant. Praxis Medicinae vniversalis, sig. $\mathrm{C}_{3}$. I603. M. Bradwood. Reges, reginae nobiles ..., sig. I verso.

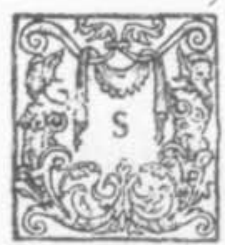

No. 30 .

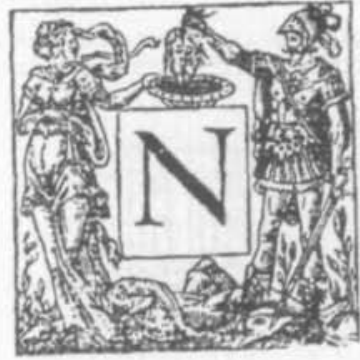

No. 32 .

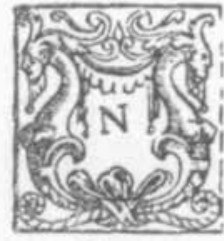

No. $3 \mathrm{I}$.

I6I2. A. Hatfield. J. Guillemeau. Child-birth . ., sig. $D_{4}$ verso.

16r6. E. Griffin. T. Scot. gent. Philomythie ..., sig. B. 1616. G. Purslowe. Epictetus manual ..., sig. A2. I622. J. Haviland. C. Burges. A chain of graces, sig. A6. This letter serves to identify a number of books that have no indication of the printer.

In addition to these initials the Eliots Court press had a number of factotums of various sorts and sizes. The smaller ones (Nos. 30, 3I) were very probably stock patterns, as they are found in numerous printing offices, including that of John Franckton in Dublin. [T he Library, June 1921, p. 45.]

One of the best known is the Salome [mm. $35 \times 35]$ (No. 32), which was most certainly in Bynneman's office and which 
was in use by several of the printers at the E.C.P. between 1585 and 1638 , and was taken to Eton by M. Bradwood in 16 Io, and is seen in the sixth vol. of the Chrysostom, sig. Gggg 6 verso. Its counterpart is also amongst the blocks of the Dublin printer, T. Franckton. It is the same size and in every respect the same drawing. The inference is that Bynneman had more than one block of this factotum, and when the Eliots Court printers bought his stock they took only the best of the blocks and the rest were sold to other printers, and this one found its way to Dublin.

This is a very superficial account of the blocks used by this firm. Nothing is said of the various devices, as most of them have already appeared in Mr. McKerrow's volume, and there were several other ornaments that have been left undescribed.

But it is hoped that it will help students to identify the work of the Eliots Court press. 